\section{Chemical Constituents and Pharmacological Properties of Capsule Gurmar- A New Anti-diabetic Formulation of Hamdard Laboratories (Waqf) Bangladesh}

\author{
Mirola Afroze ${ }^{1}$, Mridul Kabiraz ${ }^{1}$, Robiul Islam ${ }^{2}$ and *Abdul Ghani ${ }^{1}$ \\ ${ }^{1}$ Department of Pharmacy, Stamford University Bangladesh \\ 51, Siddeswari Road, Dhaka-1217, Bangladesh. \\ ${ }^{2}$ R\&D Department, Hamdard Laboratories (Waqf) Bangladesh \\ Meghnaghat, Sonargaon, Narayangonj, Dhaka, Bangladesh.
}

${ }^{*}$ Corresponding Author:

Dr. Abdul Ghani

Professor, Department of Pharmacy

Stamford University Bangladesh

51, Siddeswari Road

Dhaka-1217, Bangladesh.

Contact No.: +8801715 475910

E-mail: prof.abdulghani@gmail.com

Received - 13 April 2010

Accepted for Publication - 11 May 2010

\begin{abstract}
Capsule Gurmar is a new polyherbal Unani formulation developed by the R\&D department of Hamdard Laboratories (Waqf) Bangladesh for management and treatment of diabetes. This study was aimed to investigate the chemical constituents and analgesic, antioxidant, neuropharmacological, cytotoxic, and hypoglycemic properties of the formulation using standard methods. Phytochemical tests on the hydromethanolic extract of the contents of the capsules showed the presence of carbohydrates, glycosides, saponins, steroids, flavonoids, alkaloids and tannins in the formulation. When tested by acetic acid-induced Writhing test, the extract at higher dose $(400 \mathrm{mg} / \mathrm{kg})$ showed mild analgesic activity compared to standard drug Diclofenac-Na $(10 \mathrm{mg} / \mathrm{kg})$. But, by Tail immersion method, the extract at the same dose showed moderate analgesic activity compared to the standard drug, Nalbuphine at $10 \mathrm{mg} / \mathrm{kg}$ body weight. The Gurmar capsule extract exhibited high total antioxidant capacity $(622.326 \mathrm{mg} / \mathrm{g})$ and had high flavonoid $(386.43 \mathrm{mg} / \mathrm{g})$ and phenol $(184.60 \mathrm{mg} / \mathrm{g})$ contents. In the Hole cross and Open field tests, the extract displayed significant suppression of locomotor activity and exploratory behaviour of the mice. When subjected to Brine shrimp Lethality Bioassay, the extract was found to be significantly toxic to Brine shrimp nauplii (having $\mathrm{LC}_{50}$ value of $3.16 \mu \mathrm{g} / \mathrm{ml}$ ). Glucose Tolerance Test (GTT) demonstrated quite strong hypoglycemic activity of the formulation, which significantly lowered the blood glucose level of the treated mice both at doses of $100 \mathrm{mg}$ and $200 \mathrm{mg} / \mathrm{kg}$ body weight. The hypoglycemic effect was comparable to that of the standard oral hypoglycemic drug, Metformin hydrochloride at the dose of $100 \mathrm{mg} / \mathrm{kg}$. These results indicate that Capsule Gurmar possesses mild analgesic, antioxidant, CNS depressant, cytotoxic, and hypoglycemic properties.
\end{abstract}

Key word: capsule Gurmar, chemical constituents, pharmacological properties, hypoglycemic effects.

\title{
INTRODUCTION
}

Currently, use of herbal medicines is seriously considered as a better alternative to allopathic medicines in the treatment of many diseases, particularly the chronic ones. Capsule Gurmar is a new polyherbal Unani formulation developed by the Research and Development (R\&D) Department of Hamdard Laboratories (Waqf) Bangladesh for management and treatment of diabetes. This Formulation is recommended for various types of hyperglycemia, polyurea, especially Diabetes mellitus. It is also claimed that the product reduces obesity without balancing or dieting. The present study is an attempt to evaluate the analgesic, antioxidant, cytotoxic and hypoglycemic properties of the Gurmar capsules.

Gurmar formulation is composed of a combination of powders and aqueous dry extracts of a number of medicinal plants, which include Gymnema sylvestre, Momordica charantia, Trigonella foenum-graecum, Coccinia cordifolia and Lagerstroemia speciosa. Individually, all these plants are well known for their hypoglycemic or anti-diabetic properties because of their various special chemical constituents. Gymnema sylvestre leaves have been reported to contain triterpene saponins, such as gymnemic acids, their derivatives, gymnemasaponins, gymnemasides and various other saponin glycosides (Stocklin et al., 1968; Dateo \& Long, 1973; Yoshikawa et al., 1992; Sahu et al., 1996; Ye et al., 2001; Khramov et al., 2008]. The leaf extract contain alkaloids, glycosides, anthraquinones and their derivatives (Shanmugasundaram et al., 1990a). Oral 
administration of a water soluble fraction isolated from Gymnema sylvestre administered to diabetic patients reduced their insulin requirement, lowered the fasting blood sugar and glycosylated haemoglobin content (Shanmugasundaram et al., 1990a) and significantly increased the pancreatic islets and $\beta$-cell numbers in diabetic rats (Shanmugasundaram et al., 1990b). Alcoholic leaf extract applied orally $(500 \mathrm{mg} / \mathrm{kg}$ ) lowered maximum blood sugar in fasted, glucose fed and diabetic rats along with increased insulin release from pancreatic $\beta$-cells (Chatopadhyay et al., 1993). Gymnemic acid IV, isolated from the leaves, produced potent hypoglycemic, antihyperglycemic, glucose uptake inhibitory and gut glycosidase inhibitory effects in STZ-diabetic mice (Sugihara et al., 2000). The leaf extract has been observed to produce anti-hyperglycemic (Gholap et al., 2003) and hypoglycemic effects in corticosteroid-induced Diabetes mellitus (Gholap et al., 2004). Gymnema leaves are also noted for lowering serum cholesterols and triglycerides (Bishayee and Chatterjee, 1994). The leaf extract helps to promote weight loss by reducing cravings for sweets and controlling blood sugar levels (Ninomiya et al., 1995). The aqueous extract of $G$. sylvestre leaves induced significant anti-inflammatory activity by reducing carrageenininduced paw oedema in rats and produced significant reduction in granuloma weight, when compared to the control group (Malik et al., 2008). The aqueous extract of the leaves also possesses Free Radical Scavenging Activity and shows inhibitory effects of DPPH radicals and LDL oxidation (Ohmori et al., 2005).

A number of reported clinical studies on Momordica charantia (bitter melon) have shown that extracts from its fruits, seeds, and leaves contain several bioactive compounds that have hypoglycemic activity in both diabetic animals and humans (Yibchok-Anun et al., 2006). The major compounds that have been isolated from this plant and identified as hypoglycemic agents include a neutral non-nitrogenous principle, charantin, polypeptide-p and vicine. It also contains phenolic compounds, proteins, amino acids, vitamins of B group, ascorbic acid, minerals, glycosides and an alkaloid momordicine (Verma \& Agrawal, 1956; Okabe et al., 1980; Miyahara et al., 1981). An insulin-like peptide has been reported in this plant (Chevallier, 1996; Ghani, 2003). Charantin resembles insulin, produces hypoglycemic effect and lowers blood sugar level in rabbits (Lolitkar et al., 1966; $\mathrm{Ng}$ et al., 1986a, Srivastava et al., 1988). Polypeptide-p exhibited hypoglycemic activity without any side effects (Khanna et al., 1981) and also stimulated insulin release and blocked the formation of glucose in blood stream ( $\mathrm{Ng}$ et al., 1986b). Oleanolic acid and momordin produced anti-hyperglycemic effect by inhibiting glucose transport in intestine of rat (Matsuda et al., 1988). Extracts of $M$. charantia also show remarkable antioxidant property (Dhar et al., 2007). It has been demonstrated that the bioactive compounds present in $M$. charantia have hypolipidemic actions that can lower serum and liver cholesterol, improve glucose tolerance and reduce weight gain (Chen et al., 2003). Some of the compounds in bitter melon also improve lipid profiles (Umesh, 2005; Nerurkar, 2005).

Trigonella foenum-graecum (Fenugreek) seeds contain carbohydrates, proteins, lipids; pyridinetype alkaloids, mainly trigonelline $(0.2-0.36 \%)$, choline $(0.5 \%)$, gentianine, and carpaine; flavonoids like apigenin, luteolin, orientin, quercetin, vitexin, and isovitexin; free amino acids, calcium and iron; saponin glycosides yielding diosgenin, yamogenin, tigogenin, neotigogenin on hydrolysis, cholesterol and sitosterol; vitamins $\mathrm{A}, \mathrm{B}_{1} \mathrm{C}$, and nicotinic acid and volatile oils (Granick et al., 1996; Blumenthal et al., 2000). Treatment of diabetic patients with Trigonella foenum-graecum seeds soaked in hot water decreased FBS, TG and VLDL-C significantly (Kassaian et al., 2009). 4-Hydroxyisoleucine, an insulinotropic compound isolated from the seeds increased the insulin release in glucose-fed hyperglycemic rats and humans (Sauvaire et al., 1998). It also produced anti-hyperglycemic effect and decreased plasma triglyceride, total cholesterol and free fatty acids (Narender et al., 2006; Gupta et al., 2001). Seed powder treatment normalized the enhanced lipid peroxidation and reduced susceptibility to oxidative stress associated with depletion of antioxidants in liver of rats (Anuradha et al., 2001). Trigonella foenum-graecum seed extract also showed highly significant, dose dependent analgesic activity against thermally and chemically-induced pain comparable to that of diclofenac-sodium and pentazocine and produced marked acute antiinflammatory activity in mice (Vyas et al., 2008). It has been reported that extract of Trigonella foenum-graecum seeds contains antioxidants, exhibits scavenging of hydroxyl radicals $\left(\mathrm{OH}^{-}\right)$and inhibits hydrogen peroxide-induced lipid peroxidation in rat liver mitochondria. It also protects cellular structures from oxidative damage (Ravikumar \& Anuradha, 1999; Dixit et al., 2005).

Arial parts of Coccinia cordifolia contain proteins, fat, carbohydrates, minerals, vitamin C, steroids, $\beta$-sitosterol, phenolic compounds, triterpenoids, $\beta$-amyrin acetate and lupeol, bitter glycosidic 
constituents, alkaloids (cephalandrine A \& B), cephalandrol, tri-triacontane, heptacosane (Qudrat-ikhuda et al., 1965; Khaleque and Miah, 1968). Immature fruits contain a glycoside, cucurbitacin B, $\beta$-amyine and lupeol (Bhakuni et al., 1971). Fruits also contain $\beta$-sitosterol, taraxerone, taraxerol, and ethylcholesterol glucoside (Basu and Ghosh, 1972; Kundu and Ray, 1987). Ripe fruits contain carotenoids (Baru \& Goswami, 1979). Blood sugar lowering effect of Coccinia cordifolia has been observed in patients treated with homogenized freeze dried leaves (Khan et al., 1980). Ethanol extract of leaves and fruits produced hypoglycemic activity in diabetic albino rats and diabetic patients (Mukherjee et al., 1988; Chandrasekar et al., 1989; Hossain et al., 1992; Shibib et al., 1993; Platel et al., 1997; Kamble et al., 1998) and exhibited potent antioxidant (Venkateswaran et al., 2003) and hypolipidemic activity (Pari et al., 2003). Aqueous extract of fresh leaves of Coccinia indica produced anti-inflammatory activities in rats. The extract produced marked analgesic activity comparable to morphine. A significant reduction in hyperpyrexia in rats was also produced by the extract (Niazi et al., 2009). The antioxidant activities of the various fractions of the hydromethanolic extract of the leaves showed effective $\mathrm{H}$-donor activity reducing power, free radical scavenging activity, metal chelating ability and inhibition of $\beta$-carotene bleaching (Paliwal \& Khemani, 2006; Umamaheswari \& Chatterjee, 2008).

Leaves and fruits of Lagerstroemia speciosa have been reported to be very rich in ellagitannins and related compounds including corosolic acid and the most potent gallotannin, penta-O-galloylglucopyranose (Bai et al., 2008). Leaves also contain alanine, isoleucine, alpha-aminobutyric acid and methoeonine (Tanaka et al., 1992). The leaves of $L$. speciosa have been traditionally consumed in various forms for treatment of diabetes and kidney related diseases. All parts of the plant, particularly the old leaves and ripe fruits, contain hypoglycaemic principles having activity equivalent to 6-7.7 units of insulin (Ghani, 2003). The ellagitannins present in the plant exhibited strong activities in both stimulating insulin-like glucose uptake and inhibiting adipocyte differentiation in 3T3-L1 cells (Bai et al., 2008). Corosolic acid and Lagerstroemin isolated from the methanol extract of the leaves of Lagerstroemia speciosa have been shown to be the active compound against diabetes (Suzuki et al., 1999; Klein et al., 2007). The hypoglycemic or antihyperglycemic action of the leaves was also reported by others (Garcia, 1940; Garcia, 1941; Garcia et al., 1957; Kakuda et al., 1996; Hayashi et al., 2002; Hattori et al., 2003; Liu et al., 2001; Judy et al., 2003; Hosoyama et al., 2003; Klein et al., 2007; Klein et al., 2007; Bnouham et al., 2006; Tanquilut et al., 2009). The ethyl acetate and ethanol extracts of the leaves of Lagerstroemia speciosa were found to possess significant antioxidant and anti-inflammatory activities (Priya et al., 2008). Extracts of Lagerstroemia speciosa leaves fed with a regular diet had significantly reduced body weight and liver triglyceride of mice (Suzuki et al., 1999).

Since Capsule Gurmar has been formulated by using these plants containing such a variety of chemical constituents and pharmacological properties, which individually or collectively exhibit anti-diabetic, antioxidant, analgesic and anti-obesity activities, we became interested to see whether these pharmacological properties, particularly the cytotoxic, analgesic, antioxidant, hypoglycemic properties, were present in the formulated product, Gurmar capsule. Thus the Formulation was subjected to various preliminary phytochemical and pharmacological tests, the results of which are reported in this paper.

\section{MATERIALS AND METHODS}

\section{Phytochemical Screening}

In order to identify the different groups of chemical compounds present in Gurmar capsules (supplied by the R\&D Department of Hamdard Laboratories (Waqf) Bangladesh), a sample of 100 $\mathrm{gm}$ of the contents of the capsules was extracted with aqueous methanol $(70 \%)$. A portion of the evaporated and re-dissolved (in $10 \mathrm{ml}$ ethanol) extract was then subjected to various standard qualitative phytochemical screening tests for the detection and/or identification of different chemical compounds present in the extract (Ghani, 2003). 


\section{Pharmacological investigations}

For the experiments of analgesic, sedative and anxiolytic and anti-diabetic activity study, Swiss Albino mice of either sex, 3-4 weeks of age, weighing between 20-25 g, were collected from the International Center for Diarrhoeal Diseases and Research, Bangladesh (ICDDR, B). They were housed in groups of 5 in plastic cages. Soft wood shavings were used as bedding of cages. The animals were maintained under standard environmental conditions (temperature: $24.0 \pm 1.0^{\circ} \mathrm{C}$, relative humidity: $55-65 \%$ and $12 \mathrm{hrs}$ light/12 hrs dark cycle). Husk and excreta were removed from the cages every day. Pellets of mice foods, supplied by ICDDR, B, were given to the mice with fresh water ad libitum. The newly bought mice were given a week rest to get over the food and water restrictions incurred during transit and to get themselves adapted to the new environment of the laboratory, before being employed in any experiment.

The samples of the drug for feeding the mice were prepared in three doses $(100 \mathrm{mg} / \mathrm{kg}$ body weight, $200 \mathrm{mg} / \mathrm{kg}$ body weight and $400 \mathrm{mg} / \mathrm{kg}$ body weight) by dissolving the methanol extract of Gurmar capsule in distilled water. $90 \mathrm{mg}$ of the extract was weighed and added to $9 \mathrm{ml}$ of distilled water and mixed thoroughly with the help of a Vortex apparatus. From this solution $0.25 \mathrm{ml}$ was taken for $100 \mathrm{mg} / \mathrm{kg}$ dose, $0.50 \mathrm{ml}$ for $200 \mathrm{mg} / \mathrm{kg}$ dose and $1 \mathrm{ml}$ for $400 \mathrm{mg} / \mathrm{kg}$ dose.

\section{Pharmacological tests}

Acetic acid-induced Writhing test was considered for the screening of analgesic activity against peripheral mechanism of pain (Koster et al., 1959; Meera et al., 2008) and Tail immersion test was used to evaluate the analgesic activity against centrally mediated pain. Study of the analgesic activity of the extract of Gurmar capsules was performed in animal models (Ahmed et al., 2004; Hassan et al., 2006) for both central and peripheral mechanism of pain.

The antioxidant activity of Gurmar capsule extract was evaluated by determining the total antioxidant capacity, total phenol content and total flavonoid content of the extract according to the procedures of the phosphomolybdenum method of Prieto et al. (1999), and Kumaran \& Karunakaran (2007) respectively.

Open-field behavioral assay (Gupta et al., 1971) was used to test both locomotor and emotional activities of the mice. In this assay, the test groups received methanol extract of Gurmar capsules at the doses of $100 \mathrm{mg} / \mathrm{kg}, 200 \mathrm{mg} / \mathrm{kg}$ and $400 \mathrm{mg} / \mathrm{kg}$ body weight orally whereas the control group received vehicle (1\% Tween 80 in water). The animals in positive control group received Diazepam (1 $\mathrm{mg} / \mathrm{kg}$ body weight). Hole Cross Test was carried out according to the method described by Takagi et al. (1971) for studying the neuropharmacological activity of the mice.

Cytotoxic activity of the active constituents of the Gurmar capsule was evaluated by the Brine shrimp Lethality Bioassay of the methanol extract of the capsules using the procedure described by Meyer et al. (1982).

In order to determine the anti-hyperglycemic effect, as indicated by how quickly glucose is cleared from the blood and homeostasis is maintained, of Gurmar capsule, the Glucose Tolerance Test was performed on mice by feeding them with solutions of Gurmar capsule extract in two doses prepared by dissolving $50.4 \mathrm{mg}$ Gurmar capsule extract in $3.6 \mathrm{ml}$ distilled water $(0.2 \mathrm{ml}$ of this solution was taken for $100 \mathrm{mg} / \mathrm{kg}$ and $0.4 \mathrm{ml}$ for $200 \mathrm{mg} / \mathrm{kg}$ body weight dose). BioLand G-423 Glucometer and BioLand G-423 glucose test strips were used to measure the blood glucose levels of the mice. Metformin hydrochloride was used as a standard drug for comparison and $10 \%$ solution of pure Glucose was used for feeding the mice.

\section{RESULTS AND DISCUSSION}

\section{Phytochemical Screening}

Phytochemical screening of the methanol extract of Gurmar capsules revealed the presence, as expected, of Tannins, Flavonoids, Saponins, Alkaloids, Glycosides, Carbohydrates, Resins and Steroids. Most of these groups of chemical constituents are present in the plants, the powders or aqueous extracts of which are used in this formulation.

Alkaloids, tannins, saponins, amino acids, steroids and peptides have been reported to produce potent hypoglycemic, anti-hyperglycemic and glucose suppressive activities (Saxena et al., 2006). The above effects are produced either by insulin release from pancreatic $\beta$-cells, inhibited glucose absorption in gut, stimulated glycogenesis in liver or increased glucose utilization by the body (Grover et al., 2002; Saxena et al., 2004). These compounds also exhibited antioxidant, 
hypolipidemic, anticataract activities, restored enzymatic functions, regenerated pancreatic islets and alleviated liver and renal damage (Mukherjee et al., 2006). Since most of these compounds are present in Gurmar capsules, it is quite likely that the methanol extract of Gurmar capsule would possess hypoglycemic, anti-hyperglycemic and glucose suppressive activities.

\section{Pharmacological tests}

The hydromethanolic extract of the formulation exhibited mild analgesic effect on acetic acidinduced writhing in mice as compared to standard drug Diclofenac-Na (Table 1).

Table 1: Effect of Gurmar Capsule extract on acetic acid induced Writhing in Mice.

\begin{tabular}{ccccc}
\hline Group & Dose & Mean \pm SEM & $\%$ of Writhing & $\%$ of Inhibition \\
\hline Control & $0.4 \mathrm{ml} / \mathrm{mouse}$ & $41.3 \pm 0.64$ & 100 & 0 \\
Positive control & $10 \mathrm{mg} / \mathrm{kg}$ & $11.0 \pm 0.82$ & 21.5 & 78.5 \\
Group-1 & $100 \mathrm{mg} / \mathrm{kg}$ & $32 \pm 0.72$ & 92.25 & 7.75 \\
Group-2 & $200 \mathrm{mg} / \mathrm{kg}$ & $4.8 \pm 8.58$ & 76.75 & 23.25 \\
Group-3 & $400 \mathrm{mg} / \mathrm{kg}$ & $2.7 \pm 3.38$ & 62 & 38 \\
\hline
\end{tabular}

Control: Tween-80 + Water, Positive Control: Diclofenac-Na (10mg/kg); Group-1: Extract $(100 \mathrm{mg} / \mathrm{kg}$ ), Group-2: Extract $(200 \mathrm{mg} / \mathrm{kg})$ and Group-3: Extract $(400 \mathrm{mg} / \mathrm{kg})$.

The extract inhibited writhing response induced by acetic acid in a dose dependent manner. $400 \mathrm{mg} / \mathrm{kg}$ body weight was found to exhibit the highest (38\%) writhing response inhibitory effect. While testing the analgesic activity of the extract by the Tail-flick method, the tail withdrawal reflex time after administration of the methanol extract was found to increase with increasing dose of the extract (Fig. 1). These results thus indicated that Gurmar capsule may have analgesic activity.

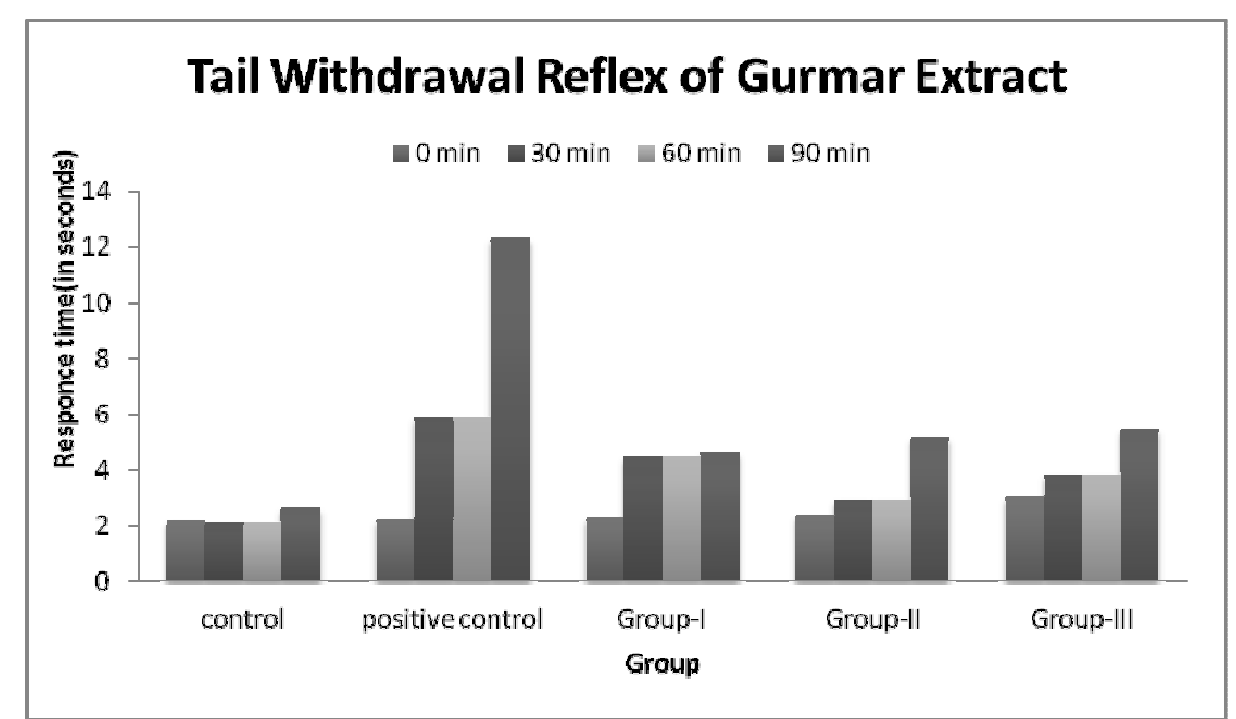

Figure 1: Effects of Gurmar Extract on tail withdrawal reflex of mice induced by TailImmersion method. Control $=1 \%$ Tween 80 in Water, $0.4 \mathrm{ml} /$ Mouse, Positive Control= Nalbuphine, $10 \mathrm{mg} / \mathrm{kg}$, Group 1=100mg/kg, Group 2=200mg/kg, Group $3=400 \mathrm{mg} / \mathrm{kg}$ body weight.

The Gurmar capsule extract exhibited high total anti-oxidant capacity $(622.33 \mathrm{mg} / \mathrm{g})$, which correlates well with its rich flavonoid $(386.43 \mathrm{mg} / \mathrm{g}$ ) and phenol $(184.60 \mathrm{mg} / \mathrm{g})$ contents (Table 2). The free radical scavenging and antioxidant activities of the extract may be attributed to the high quantities of flvonoids and phenolic compounds (tannins) present in it. One of the factors implicated in the development of diabetes is the damage induced by free radicals and hence an anti-diabetes formulation with antioxidant components would be more beneficial (Manisha et. al., 2007). Thus the antioxidant property exhibited by Gurmar capsule strengthens its quality as a potential anti-diabetic drug. 
Table 2: Total antioxidant capacity, total phenol content and total flavonoid content of the hydromethanolic extract of Gurmar.

\begin{tabular}{|c|c|c|c|}
\hline Sample & $\begin{array}{c}\text { Total antioxidant } \\
\text { capacity } \\
\text { ( } \mathrm{mg} / \mathrm{g} \text {, in } \mathrm{AAE})\end{array}$ & $\begin{array}{c}\text { Total phenol } \\
\text { content } \\
\text { (mg/g, in GAE) }\end{array}$ & $\begin{array}{c}\text { Total flavonoid } \\
\text { content } \\
\text { (mg/g, QE) }\end{array}$ \\
\hline Gurmar extract & $622.33 \pm 5.76$ & $184.60 \pm 7.17$ & $386.43 \pm 28.86$ \\
\hline
\end{tabular}

In both Open field and Hole cross tests, the extract significantly decreased the locomotor activity of the mice (Table 3 and 4). The locomotor activity lowering effect (depressant effect) was evident at the 2nd observation time (at $30 \mathrm{~min}$.) and continued up to the 5 th observation period (at $120 \mathrm{~min}$.) at the doses of $100,200 \& 400 \mathrm{mg} / \mathrm{kg}$ body weight and the results were dose dependent, the maximum being at the dose of $400 \mathrm{mg} / \mathrm{kg}$ body weight. In the Open field test, the number of squares travelled by the mice at all doses of the extract $(100 \mathrm{mg} / \mathrm{kg}, 200 \mathrm{mg} / \mathrm{kg}$ and $400 \mathrm{mg} / \mathrm{kg}$ body weight) was reduced significantly from the initial score. The results were comparable to those of the reference drug, Diazepam. The maximum reduction was exhibited at 90 and $120 \mathrm{~min}$. after administration of the drug.

Table 3: Effect of extract of Gurmar as exhibited By Open field test in Mice.

\begin{tabular}{ccccccc}
\hline \multirow{2}{*}{ Group } & $\begin{array}{c}\text { Route of } \\
\text { Administration }\end{array}$ & \multicolumn{5}{c}{ Observation } \\
\cline { 3 - 7 } & Oral & $121.6 \pm 5.35$ & $117.8 \pm 3.94$ & $\mathbf{6 0} \mathbf{~ m i n}$ & $\mathbf{9 0} \mathbf{~ m i n}$ & $\mathbf{1 2 0} \mathbf{~ m i n}$ \\
\hline Control & Oral & $118.6 \pm 2.617 .04$ & $67.8 \pm 5.63$ & $41.6 \pm 3.65$ & $110.8 \pm 7.53$ & $117.2 \pm 4.62$ \\
Positive & Oral & $95.2+19.61$ & $46.6+1042$ & $35 \pm 9.61$ & $31.60 \pm 9.29$ & $30.20 \pm 1.88$ \\
control & Oral & $48.4 \pm 11.52$ & $41.6 \pm 2.89$ & $20.4 \pm 5.68$ & $26 \pm 5.94$ & $17 \pm 2.32$ \\
Group-1 & Oral & $81.4 \pm 9.39$ & $43 \pm 10.45$ & $37.2 \pm 2.04$ & $35.4 \pm 8.41$ & $21.8 \pm 5.41$ \\
Group-2 & Group-3 & &
\end{tabular}

Control: Tween-80 + Water, Positive Control: Diazepam (1mg/kg), Group-1: Extract (100mg/kg), Group-2: Extract $(200 \mathrm{mg} / \mathrm{kg})$ and Group-3: Extract $(400 \mathrm{mg} / \mathrm{kg})$.

Table 4: Effect of Extract of Gurmar Capsule on Hole cross test in Mice.

\begin{tabular}{|c|c|c|c|c|c|c|}
\hline \multirow{2}{*}{ Group } & \multirow{2}{*}{ Dose } & \multicolumn{5}{|c|}{ Observation } \\
\hline & & $0 \mathrm{~min}$ & $30 \mathrm{~min}$ & $60 \mathrm{~min}$ & $90 \mathrm{~min}$ & $120 \mathrm{~min}$ \\
\hline Control & $0.4 \mathrm{ml} / \mathrm{mouse}$ & $17 \pm 1.97$ & $17.8 \pm 1.92$ & $17.6 \pm 2.28$ & $17.2 \pm 1.56$ & $18.4 \pm 0.91$ \\
\hline $\begin{array}{c}\text { Positive } \\
\text { control }\end{array}$ & $1 \mathrm{mg} / \mathrm{kg}$ & $15.4 \pm 0.91$ & $6 \pm 0.94$ & $2 \pm 0.79$ & $1.6 \pm 1.04$ & $1.2 \pm 0.42$ \\
\hline Group 1 & $100 \mathrm{mg} / \mathrm{kg}$ & $12.60 \pm 3.21$ & $9.0 \pm 0.612$ & $8.60 \pm 1.4$ & $4.20 \pm 1.475$ & $3.20 \pm 0.96$ \\
\hline Group 2 & $200 \mathrm{mg} / \mathrm{kg}$ & $9.40 \pm 1.26$ & $5.20 \pm 1.29$ & $4.00 \pm 0.79$ & $3.40 \pm 1.51$ & $2.20 \pm 0.82$ \\
\hline Group 3 & $400 \mathrm{mg} / \mathrm{kg}$ & $8.60 \pm 1 . .26$ & $8.40 \pm 0.837$ & $6.00 \pm 0.79$ & $6.00 \pm 0.79$ & $2.40+0.27$ \\
\hline
\end{tabular}

Control: Tween-80 + Water, Positive Control: Diazepam (1mg/kg), Group-1: Extract (100mg/kg), Group-2: Extract $(200 \mathrm{mg} / \mathrm{kg})$ and Group-3: Extract $(400 \mathrm{mg} / \mathrm{kg})$.

While testing the effect of Gurmar capsule extract on neuropharmacological activity of the mice by the Hole cross test, the extract produced significant decrease of movement at the dose levels of $100 \mathrm{mg} / \mathrm{kg}, 200 \mathrm{mg} / \mathrm{kg}$ and $400 \mathrm{mg} / \mathrm{kg}$ body weight, the maximum decrease in movement was observed at 90 and $120 \mathrm{~min}$. after administration of the drug.

The hydromethanolic extract of Gurmar capsules showed significant cytotoxic activity against Brine Shrimp nauplii with $\mathrm{LC}_{50}$ of $3.16 \mu \mathrm{g} / \mathrm{ml}$ while the $\mathrm{LC}_{50}$ of the reference anticancer drug vincristine sulphate was $0.66 \mu \mathrm{g} / \mathrm{ml}$ (Table 6). The extract produced concentration dependent increment in percent mortality of Brine Shrimp nauplii. The degree of lethality shown by the extract was found to be directly proportional to the concentration of the extract ranging from the lowest concentration of 
$1.25 \mu \mathrm{g} / \mathrm{ml}$ to the highest concentration of $320 \mu \mathrm{g} / \mathrm{ml}$. This concentration dependent increment in percent mortality of Brine Shrimp nauplii produced by the Gurmar extract indicates the presence of potent cytotoxic principles in the extract. Alkaloids, phenolics (tannins), flavonoids, triterpenoids and steroids, which are present in Gurmar capsule, are well known for their cytotoxic activity (Badami et al., 2003; Chang et al., 2000; Dhar et al., 1973; Vijayan et al., 2004). So the cytotoxicity produced by the Gurmar is not without justification.

Table 5: Cytotoxic potential of crude hydromethanolic extract of Gurmar.

\begin{tabular}{ccc}
\hline Test Solution & LC $_{50}(\mu \mathrm{g} / \mathrm{ml})$ & LC $_{90}(\boldsymbol{\mu g} / \mathbf{m l})$ \\
\hline Gurmar Extract & 3.16 & 100 \\
Vincristine & 0.66 & 7.9 \\
sulphate & & \\
\hline
\end{tabular}

The results of the Glucose tolerance test showed that the Gurmar capsule extract possesses significant anti-hyperglycemic effect, as indicated by significant decrease of blood glucose level with increasing time span at dose levels of $100 \mathrm{mg} / \mathrm{kg}$ and $200 \mathrm{mg} / \mathrm{kg}$ body weight. These results compared very well with those of the standard potent anti-hyperglycemic drug, Metformin $\mathrm{HCl}$ (Table 6).

As evident from the literature review, it is strongly revealed that all the plants involved in the formulation of Gurmar capsule contain anti-diabetic, hypoglycemic, anti-hyperglycemic and antioxidant properties (Abdel Barry et al., 1997; Gholap et al., 2004; Harinantenaina et al., 2006; Krawinkel et al., 2006; Mukherjee et al., 1988; Shanmugasundaram et al., 1990a).

Table 6: Results of Glucose Tolerance Test of Gurmar Capsule.

\begin{tabular}{cccccc}
\hline Test Group & Dose (mg/kg) & $\mathbf{0} \mathbf{~ m i n}$ & $\mathbf{3 0} \mathbf{~ m i n}$ & $\mathbf{6 0} \mathbf{~ m i n}$ & $\mathbf{1 2 0} \mathbf{~ m i n}$ \\
\hline Control & $0.4 \mathrm{ml} / \mathrm{mouse}$ & $5.9 \pm 0.47$ & $9 \pm 0.81$ & $6.84 \pm 0.75$ & $4.86 \pm 0.51$ \\
Positive Control & 100 & $4.72 \pm 0.35$ & $6 \pm 0.81$ & $4.26 \pm 0.21$ & $3.92 \pm 0.2$ \\
Group-1 & 100 & $5.18 \pm 0.5$ & $7.82 \pm 0.33$ & $6.18 \pm 0.16$ & $4.4 \pm 0.39$ \\
Group-2 & 200 & $5.2 \pm 0.24$ & $7.64 \pm 0.88$ & $6.26 \pm 0.4$ & $4.2 \pm 0.38$ \\
\hline
\end{tabular}

So it is not unusual that the extracts of Gurmar capsules showed significant hypoglycemic effects (lowering the blood glucose level with increasing time) in mice as demonstrated by the Glucose tolerance test. These comparable results clearly indicate that the Gurmar capsule, developed by Hamdard Laboratories (Waqf) Bangladesh, is an effective anti-hyperglycemic drug.

\section{CONCLUSION}

The Gurmar formulation has been indicated for the treatment and management of hyperglycemia, polyurea, especially Diabetes mellitus, obesity and hyperlipidemia. Based on the findings of the present study, it can be said that the Gurmar capsule may be used for the treatment and management of these metabolic disorders since this formulation possesses significant antioxidant, hypoglycemic, analgesic, cytotoxic, and CNS depressant properties.

\section{ACKNOWLEDGEMENT}

We would like to thank the authorities of Hamdard Laboratories (Waqf) Bangladesh for supplying the Gurmar capsules and the Department of Pharmacy, Stamford University Bangladesh for providing all necessary laboratory facilities for conducting this research.

\section{REFERENCES}

Abdel Barry, J.A., Abdel Hassan I.A. \& Al-Hakiem M.H. (1997). J. Ethnopharmacology, 58: 149155.

Ahmed, F., Selim, M.S.T., Das, A.K. \& Choudhuri, M.S.K. (2004). Pharmazie, 59: 329-333.

Anuradha, C.V. \& Ravikumar, P. (2001). Ind. J. Physiol. Pharmacol. 45: 408-420. 
Badami, S., Manohara Reddy, S..A, Kumar E.P., Vijayan, P. \& Suresh, B. (2003). Phytother. Res. 17: 1001-1004.

Bai Naisheng, He Kan, Rolle Marc, Zheng Bolin, Chen Xiaozhuo, Shao Zhongguang , Peng Tangsheng \& Zheng Qunyi (2008). J. Agric. Food Chem. 56 (24), 11668-1674.

Baru, A.B. \& Goswami, B.C. (1979). Current Science, 48 (14), 630-632.

Basu, K. \& Ghosh, B.K. (1972). Ttrans. Bose Research Institute, Calcutta, India, 35 (2): 43.

Bhakuni D.S., Dhar M.L., Dhar, M.M. \& Dhawan, B.N. (1971). Ind. J. Exp. Biol. 9: 91-102.

Bishayee, A. \& Chatterjee, M. (1994). Phytotherapy Res. 8 (2): 118-120.

Blumenthal, Goldberg, Brinckman. Herbal medicine: expanded Commission E monographs. Integrative Medicine Communications, 2000.

Bnouham Mohamed, Ziyyat Abderrahim, Mekhfi Hassane, Tahri Abdelhafid \& Legssyer Abdelkhaleq (2006). Int. J. Diabetes \& Metabolism, 14: 1-25.

Chandrasekar, B., Mukherjee, B. \& Mukherjee, S.K. (1989). Ind. J. Med. Res. 90: 300-305.

Chang, Y.C., Tai, K.W., Huang, F.M. \& Huang, M.F. (2000). J. Endodontics, 26 (8): 440-443.

Chatopadhyay, R.R., Medda, C., Das, S. \& Basu, T.K. (1993). Fitoterapia, 64: 450-454.

Chen, Q., Chan, L.L.Y., \& Li, E.T.S. (2003). J. Nutr. 133: 1088-1093.

Chevallier, Andrew (1996), The Encyclopedia of Medicinal Plants, 1st edn., DK Publishing Inc., New York, USA.

Dateo, G.P. \& Long, L. (1973). African J. Agric. Food Chem. 21: 899-903.

Dhar, P., Chattopadhyay, K., Bhattacharyya, D. Roychoudhury, A., Biswas, A., \& Ghosh, S. (2007). J. Oleo Sci. 56:19-24.

Dhar, M.L., Dhar, M.N., Dhawan, B.N., Mehrotra, B.N., Srimat, R.C. \& Tandon, J.S. (1973). Indian J. Exp. Biol. 11: 43-45.

Dixit, P.P., Ghaskadbi, S.S., Hari, M. \& Devasagayam, T.P.A. (2005). Phytother. Res. 19, 977983.

Garcia, F. \& Melencio-Maglalang, P. (1957). J. Phil. Med Assoc. 33 (1): 7-15.

Garcia, F. (1940). J. Phil. Med. Assoc. 20: 395-402.

Garcia, F. (1941). Acta Med. Philippina. 3: 99-104.

Ghani, A. (2003). Medicinal Plants of Bangladesh with Chemical Constituents and Uses, 2nd edn., Asiatic Society of Bangladesh, Dhaka.

Gholap, S. \& Kar, A. (2003). Pharmazie, 58: 413- 415.

Gholap, S. \& Kar, A. (2004). Pharmazie, 59: 876-878.

Granick, B., Neubauer, D., DerMarderosian, A. (1996). The Lawrence Review of Natural Products. St. Louis: Facts and Comparisons, pp. 1-3.

Grover, J.K., Yadav, S. \& Vats, V. (2002). J. Ethnopharmacology, 81: 81-100.

Gupta, B.D., Dandiya, P.C., Gupta, M.L. (1971). Japan J. Pharmacol. 21:293

Gupta, A., Gupta, R. \& Lal, B. (2001). J. Assoc. Phys. India, 49: 1057-1061.

Harinantenaina, L., Tanaka, M., Takaoka, S., Oda, M., Mogami, O., Uchida, M. \& Asakawa, Y. (2006). Chem. Pharm. Bull. 54: 1017-1021.

Hassan,A.M., Wagdy, K.B., Khalil \& Kawkab, A.A. (2006). African J. Biotechnology, 5 (5): 477-483.

Hattori, K., Sukenobu, N., Sasaki, T., Takasuga, S., Hayashi, T. \& Kasai, R. (2003). J. Pharmacol. Sci. 93 (1): 69-73.

Hayashi, T., Maruyama, H., Kasai, R., Hattori, K., Takasuga, S \& Hazeki, O. (2002). Planta Medica, 68 (2): 173-175.

Hosoyama, H., Sugimoto, A., Suzuki, Y., Sakane, I. \& Kakuda, T. (2003). Yakugaku Zasshi. 123 (7): 599-605.

Hosoyama, H., Sugimoto, A., Suzuki, Y., Sakane, I., Kakuda, T. (2003). Yakugaku Zasshi. 123 (7): 599-605.

Hossain, M.Z., Shibib, B.A. \& Rahman, R. (1992). Ind. J. Exp. Biol. 30: 418-420. 
Judy, W.V., Hari, S.P., Stogsdill, W.W., Judy, J.S., Naguib, Y.M. \& Passwater, R. (2003). J. Ethnopharmacology, 87 (1): 115-117.

Kakuda, T., Sakane, I. Takihara, T., Ozaki, Y., Takeuchi, H. \& Kuroyanagi, M. (1996). Biosci. Biotechnol. Biochem. 60 (2): 204-208.

Kamble, S.M., Kamlakar, P.L., Vaidya, S. \& Bambole, V.D. (1998). Ind. J. Med. Sc. 52: 143-146.

Kassaian, N., Azadbakht, L., Forghani, B. \& Amini, M. (2009). Int. J. Vitam. Nutr. Res. 79 (1): 3439.

Khaleque, A., Miah, W., Alam, M.N. \& Amin, S. (1968). Scientific Research (Dacca), 5 (1): 66.

Khan, A.K.A., Akhtar, S. \& Mahatab, H. (1980). Brit. Med. J. 280 (6220): 1044.

Khanna, P., Jain, S.C., Panagariya, A., \& Dixit, V.P. (1981). J. Nat. Prod. 44: 648-655.

Khramov, V.A., Spasov, A.A. \& Samokhina, M.P. (2008). Pharm. Chem. J. 42 (1): 29-31.

Klein, G., Kim, J., Himmeldirk, K., Cao, Y. \& Chen, X. (2007). eCAM. 4 (4): 401-407.

Koster, R., Anderson, M. \& de Beer, E.J. (1959). Fed. Proc. 18: 412.

Krawinkel, M.B. \& Keding, G.B. (2006). Nutr. Rev. 64: 331-337.

Kundu, S. \& Ray, A.B. (1987). J. Indian Chem. Soc. 65 (12): 776-777.

Kumaran, A. \& Karunakaran, R.J. (2007). LWT. 40: 344-352.

Liu, F., Kim, J., Li, Y., Liu, X., Li, J. \& Chen, X. (2001). J. Nutr. 131 (9): 2242-2247.

Lolitkar, M.M., Rao, M.R.R. (1966). Ind. J. Pharmacy, 28: 129-133.

Malik, J.K., Manvi, F.V., Alagawadi, K.R. \& Noolvi, M. (2008). Int. J. Green Pharm, 2 (2): 114-115.

Manisha, M., Prianjali, D., Jaynt, L. Saroj, G. \& Thomas, P.A.D. (2007). J. Clin. Biochem. Nutr. 40: 163-173.

Matsuda, H., Li, Y., Murakami, T., Matsumura, N., Yamahara, J. \& Yoshikawa, M. (1988). Chem. Pharma. Bull. 46: 1399-1403.

Meera, S., Kumar, N.S. \& Guptatyam, V.S.S. (2008). Int. J. Pharmacol. 4 (5): 398-402.

Meyer, B.N., Ferringni, N.R., Puam, J.E., Lacobsen, L.B., Nichols, D.E. \& McLaughlin, J.L. (1982). Planta Medica, 45: 31-32.

Miyahara, Y., Okabe, H. \& Yamauchi, T. (1981), Chemical \& Pharmaceutical Bulletin (Tokyo), 29 (6): 1561-1566.

Mukherjee, B., Sekar, B.C. \& Mukherjee, S.K. (1988). Fitoterapia, 59: 207-210.

Mukherjee, P.K., Maiti, K., Mukherjee, K. \& Houghton, P.J. (2006). J. Ethnopharmacology, 106: 128.

Narender, T., Puri, A., Shweta, Khaliq, T., Saxena, R., Bhatia, G. \& Chandra, R. (2006). Bioorg. Med. Chem. Lett. 16: 293- 296.

Nerurkar Pratibha, V., Laurel Pearson, Jimmy T. Efird, Khosrow Adeli, Andre G. Theriault \& Vivek R. Nerurkar (2005). J. Nutr. 135 (4): 702-706.

Ng, T.B., Wong, C.M., Li, W.W. \& Yeung, H.W. (1986a). J. Ethnopharmacology, 15: 107-117.

Ng, T.B., Wong, C.M., Li, W.W. \& Yeung, H.W. (1986b). International J. Peptide Protein Research, 28: 163-172.

Niazi Junaid, Singh Parabhdeep, Bansal Yogita \& Goel R. K. (2009), Inflammopharmacology, 17 (4): 239-244.

Ninomiya, Y. \& Imoto, T. (1995). American J. Physiology, 268 (4): 1019-1025.

Ohmori, R., Iwamoto, T., Tago, M., Takeo, T., Unno, T., Itakura, H. (2005). Lipids, 40 (8): 849-853.

Okabe, H., Miyahara, Y., Yamauchi, T., Miyahara, K. \& Kawanishi,T. (1980). Chemical \& Pharmaceutical Bulletin (Tokyo). 28 (9): 2753-2762.

Paliwal Pritee \& Khemani, L.D. (2006). The Indian Journal of Veterinary Research, 15 (2).

Pari, L. \& Venkateswaran, S. (2003). Pharmazie, 58: 409-412.

Platel, K. \& Srinivasan, K. (1997). Die Nahrung, 41: 68-74.

Prieto, P.M., Pineda, M. \& Aguilar, M. (1999). Anal. Biochem. 269: 337-341. 
Priya, T.T., Sabu, M.C. \& Jolly, C.I. (2008). Inflammopharmacology, 16 (4): 182-187.

Qudrat-i-Khuda, M., Khaleque, K.A. \& Miah, M.A.W. (1965). Scientific Research (Dacca). 2 (1\& 2): 27-31.

Ravikumar, P. \& Anuradha, C.V. (1999). Phytother. Res. 13: 197-201.

Sahu, N.P., Mahato, S.B., Sarkar, S.K. \& Poddar. G. (1996). Phytochemistry, 41 (4): 1181-85.

Sauvaire, Y., Petie, P., Broca, C., Manteghetti, M., Baissac, Y., Fernandez-Alvarez, J., Gross, R., Roye, M., Leconte, A., Gomis, R. \& Ribes, G. (1998). Diabetes, 47: 206-210.

Saxena, A. \& Vikram, N.K. (2004). J. Alt. Compl. Medicine, 10: 369-378.

Saxena, A.M., Mukherjee, S.K. \& Shukla, G. (2006). National Institute of Science Communication (CSIR), New Delhi, 1-104.

Shanmugasundaram, E.R.B., Rajeswari, G., Bhaskaran, K., Kumar, B.R.R., Shanmugasundaram, K.R. \& Ahmath, B.K. (1990a). J. Ethnopharmacology, 30: 281-294.

Shanmugasundaram, E.R.B., Gopinath, K.L., Shanmugasundaram, K.R. \& Rajendran, V.M. (1990b). J. Ethnopharmacology, 30: 265-279.

Shibib, B.A., Khan, L.A. \& Rahman, R. (1993). Biochem. J. 292: 267-270.

Srivastava, Y., Venkatakrishna-Bhatt, H. \& Verma, Y. (1988). Pharmacol. Res. Commun. 20: 201209.

Stocklin, W. (1968). Helv. Chim. Acta, 51 (6): 1235-1242.

Sugihara, Y., Nojima, H., Matsuda, H., Murakami, T., Yoshikawa, M. \& Kimura, I. (2000). J. Asi. Natur. Product. Res. 2: 321-327.

Suzuki, Y., Unno, T., Ushitani, M., Hayashi, K. \& Kakuda, T. (1999). J. Nutr. Sci. Vitaminol. 45: 6 791-795.

Takagi, K., Watanabe, M. \& Saito, H. (1971). Jpn. J. Pharmacol. 21: 797-810.

Tanaka, T., Tinuma, M., Yuki, K., Fujii, Y. \& Mizunu, M. (1992). Phytochemistry, 31 (3): 993-998.

Tanquilut, N.C., Tanquilut, M.R.C., Estacio, M.A.C., Torres, E.B., Rosario, J.C. \& Reyes, B.A.S. (2009). Journal of Medicinal Plants Research, 3 (12):1066-1071.

Umamaheswari, M. \& Chatterjee, T.K. (2008). African J. Trad. Compl. Altern. Medicines, 5 (1): 61 73.

Umesh, C.S., Yadav K. Moorthy \& Najma Z. Baquer (2005). Molecular and Cellular Biochemistry, 268 (1-2): 111-120.

Venkateswaran, S. \& Pari, L. (2003). J. Ethnopharmacology, 84: 163-168.

Verma \& Agrawal (1956). Journal of Indian Chemical Society, 33: 357.

Vijayan, P., Rreethi, V., Prashanth, S.H., Raghu Chandrashekhar, H., Ashok, G. \& Shrishailappa, B. (2004). Biol. Pharm. Bull. 27: 528-530.

Vikas Jain, Dugapati Girish \& Avinash Kumar Dorle (2006). Journal of Herbal Pharmacotherapy, 6 (3-4): 105-115.

Vyas, S., Agrawal, R.P., Solanki, P. \& Trivedi, P. (2008). Acta Pol. Pharm. 65 (4): 473-476.

Ye, W., Liu, X., Zhang, Q., Che, C.T. \& Zhao, S. (2001). J. Nat. Prod. 64 (2): 232-235.

Yibchok-Anun, S., Adisakwattana, S., Yao, C.Y., Sangvanich, P., Roengsumran, S., \& Haw Hsu, W. (2006). Biol. Pharm. Bull. 29: 1126-1131.

Yoshikawa, K., Nakagawa, M., Yamamoto, R., Arihara, S. \& Matsuura, K. (1992). Chem. Pharma. Bull. 40: 1779-82. 